https://doi.org/10.5800/GT-2017-8-3-0266

\title{
PETROGENESIS AND RARE METAL MINERALIZATION OF THE ALKALINE GRANITIC MAGMA: A CASE STUDY FROM THE BOZIGUO'ER RARE METAL GRANITIC INTRUSION
}

\author{
He Huang1, Tao Wang1' Zhaochong Zhang'2, Qie Qin ${ }^{1}$ \\ ${ }^{1}$ Institute of Geology, Chinese Academy of Geological Sciences, Beijing 100037, China \\ ${ }^{2}$ State Key Laboratory of Geological Processes and Mineral Resources, China University of Geosciences, \\ Beijing 100083, China
}

For citation: Huang H., Wang T., Zhang Z., Qin Q., 2017. Petrogenesis and rare metal mineralization of the alkaline granitic magma: a case study from the Boziguo'er rare metal granitic intrusion. Geodynamics \& Tectonophysics 8 (3), 475-476. doi:10.5800/GT-2017-8-3-0266.

The origination and differentiation of rare metalbearing, alkaline granites has attracted extensive interests because of their economic significance. The Early Permian ( $290 \mathrm{Ma})$ Boziguo'er alkaline granitic intrusion, exposed in the middle segment of the South Tianshan Terrane, Xinjiang, NW China, is enriched in Nb-Ta-, Zr-, Th-U- and REE-bearing accessory minerals, and can be regarded as a large rare metal deposit [Huang et al., 2014; Liu et al., 2013]. Although the subsolidus alteration occurred ubiquitously in the intrusion, the degree of enrichment of rare metal elements seems unrelated to that of the albitization or greisenization. The unalterated alkaline granites of the intrusion is mainly composed of orthoclase $(\sim 30$ vol. \%), albite $(\sim 40$ vol. $\%)$, quartz $(\sim 15$ vol. \%), biotite $(\sim 10$ vol. $\%)$ and arfvedsonite ( $~ 5$ vol. \%), with accessory minerals at least including zircon, Fe-Ti oxides, monazite, pyrochlore, xenotime, bastnasite and astrophyllite. The existence of two feldspars, which respectively show nearly pure $\mathrm{Ab}$ and Or end member compositions, suggest that the Boziguo'er alkaline granitic rocks can be classified as "subsolvus granites". The high contents of fluorine in the hydrous minerals suggest a fluorine-rich characteristic at the latest magmatic stage, which would not only prolong the duration of the magmatic differentiation but can also act as a complexing agent with HFSEs and REEs. A semiquantitative calculation, based on mineral compositions of analyzed biotites, yields results of 0.70 to $2.14 \mathrm{wt}$. \% (with an average of $1.25 \mathrm{wt}$. \%) for $\mathrm{F}$ contents in 
granitic melts. Considering relatively low whole-rock fluorine concentrations (2187 to $8833 \mathrm{ppm}$ ) as well as the positively linear correlation between whole-rock $\mathrm{CaO}$ and $\mathrm{F}$, implying that most fluorine initially incorporated in the melts were likely removed because of the separation of Ca-fluoride melt and silicate melt.
Given the abundance of mineral and melt inclusions with fluorite, albite and monazite compositions enclosed by zircons crystallized at latest magmatic stage, the fluoride-silicate melt immiscibility likely took place at the late magmatic stage and represent the initiation of the rare metal minerallization.

\section{REFERENCES}

Huang H., Zhang Z.C., Santosh M., Zhang D.Y., 2014. Geochronology, geochemistry and metallogenic implications of the Boziguo'er rare metal-bearing peralkaline granitic intrusion in South Tianshan, NW China. Ore Geology Reviews 61, 157-174. https://doi.org/10.1016/j.oregeorev.2014.01.011.

Liu C.H., Yin J.W., Wu C.L., Shao X.K., Yang H.T., Xu H.M., Wang J., 2013. The geochemical and zircon trace elements characteristics of A-type granitoids in Boziguoer, Baicheng County, Xinjiang. Acta Geologica Sinica 87 (6), 1585-1603. https://doi.org/10.1111/1755-6724.12161. 